\title{
The Shadow Economy: A Bibliometric Analysis
}

http://doi.org/10.21272/bel.4(3).107-118.2020

Zolkover Andrii, ORCID: https://orcid.org/0000-0002-8176-1850

$\mathrm{PhD}$, Doctoral student, the Department of business economics and tourism, Kyiv National University of Technologies and Design, Ukraine

Venelin Terziev, ORCID: https://orcid.org/0000-0003-1115-8877

Professor, Eng., D.Sc. (National Security), D.Sc. (Economics), D.Sc. (Social Activities), Ph.D. Georgi Rakovski Military Academy, Sofia, Bulgaria University of Rousse, Rousse, Bulgaria Kaneff University Hospital, Rousse, Bulgaria

\section{Abstract}

The article deals with the analysis of the areas of research related to the shadow economy. The results of analyses show that financial market and financial intermediates become an essential part of the issues and that the topic of the problem of poverty among the urban population, low income, drugs abuse and problems of female employment, gender inequity in income in the papers which analyzed the shadow economy issues are very popular. The aim of the paper is to analyze the tendency in the scientific literature on the shadow economy to identify future research directions. For the analysis, the tools of VOSviewer, Scopus and Web of Science (WoS) analyses were used. This study is based on 5361 papers from Scopus and 3773 papers from Web of Science. The time sample of research was not limited for analysis. Time analysis showed that in 2014-2015 the number of papers dealing the shadow economy began to increase. At the same time, the focal point of research moved from general issues (estimation of shadow sector, impact on labour market etc.) to problem of transition from the informal to the formal Economy. In 2019 the number of papers which analyzed the the shadow economy was increased by $95 \%$ compared with the 2014 year, according to Scopus database - by 29\%. Mostly the papers with keyword "shadow" (informal, hidden etc.) economy were published under the following subject area, according to Scopus: Social science; Economics, Econometrics and Finance; Business, Management and Accounting; Environmental Science; Arts and Humanities, and according to WoS: Business Economics; Sociology; Public Administration; Government Law; Development Studies; Social Sciences Other Topics; Environmental Sciences Ecology; Area Studies. Most articles focused on shadow economy were published by the scientists from the USA, United Kingdom, India, Germany and South Africa. In 2019 considering the findings from Scopus the high ranked Studies in Systems Decision and Control, Journal of Business Ethics, Journal of Contemporary Asia, Cities stated to publish papers devoted to shadow economy. Such results prove that informal economy theme and its transition to formal is in the ongoing trends of the modern regulation. The findings from VOSviewer identified six clusters of the papers which investigate the shadow economy from the different points of views. The first most significant cluster merged the paper which contained the keywords as follows: informal sector, informal economy, unemployment, gender, urban economy, labour market, corruption etc. The papers in the second largest cluster deal with poverty among urban population, low income, drugs abuse and problems of female employment, gender inequity in income. The third biggest cluster focuses on criminal and ecological aspects of shadow economy.

Keywords: Shadow Economy, Shadow Sector of Economy, Informal Economy, Informal Sector of Economy, Underground Economy, Underground Sector of Economy, Hidden Economy, Hidden Sector of Economy.

JEL Classification: O17, E26.

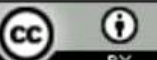

c. This work is licensed under a Creative Commons Attribution 4.0 International License

Cite as: Zolkover, A., Terziev, V. (2020). The Shadow Economy: A Bibliometric Analysis. Business Ethics and Leadership, 4(3), 107-118. http://doi.org/10.21272/bel.4(3).107-118.2020.

(C) The Authors, 2020. This article is published with open access at Sumy State University.

\section{Introduction}

Since the appearance of the terminology "informal economy" in the 20 century, it and its role in economic development have been hotly polemicized. Some scientists define the informal economy as a ground for entrepreneurial talents' rising or a margin of safety during financial crises. Others view, arguing that informal entrepreneurs consciously avoid regulation and taxation. At the same time, others see the informal economy as a support and livelihood source for the poor and unqualified workers. Each of these points of view is correct 
regarding specific components or aspects of the informal economy. The terminology "shadow" (hidden, informal, underground etc.) economy in publications related to shadow economy started to be used more frequently after the World Health Organization Guidelines for the decriminalization of illicit drugs and when many countries are imposing stricter requirements on the quality of food, children's toys and other household items with aims for the use of safe chemical compounds., both by academics and law professionals. This paper presents a literature review of the articles dedicated to different aspects of the shadow economy, relationships, and co-citations. The first study aim is summarizing the level of paper about the shadow economy and connected spheres. Second, we will tie in published material devoted to the shadow economy to define the terminology of what areas have strong connections with shadow economy issues. Although, the first mention of the informal economic sector is associated with (Lewis, W. A., 1955) or (ILO, Geneva, 1972) and traditionally analyzed with the labor market, the vast range of modern scientists in the papers analyzing the shadow economy act in the same way in the context of its estimation, labour market, financial system, etc. Considering this, we used the simple of papers published in Clarivates, ScienceDirect, Scopus or Web of Sciences and the link between keywords in the sphere shadow economy (impact on economic growth, level of skills of employees in the hidden sector, calculation of its correlation with depth of financial crises, etc.) to propose future areas of study.

\section{Literature Review}

The widespread use of the shadow economy terminology in academic literature relates to many areas, including informal urban economy, unemployment and informal employment, the impact of the informal sector of the economy on the state of environmental pollution, rural-urban migration, crime, etc. As we noted earlier, Nobel laureate Arthur W. Lewis was the first author who mentioned "informal sector" when listed in his paper (Lewis, W.A., 1955) some of the sources of infinite elasticity of labor supply: "...underemployment in urban areas, in what has now come to be called the informal sector...". But in many papers published by the International Labour Organisation, ILO claims primacy in applying this definition, especially about the whole economy. Thus, according to paper (ILO, Geneva, 1972), the term "informal sector" was first coined in 1972, at the outcome of a comprehensive ILO employment advisory mission to Kenya, and was later converted to "informal economy" to underline the fact that informality is not a "sector," but a particular way of carrying out economic activities. Interestingly, that in the paper (Bangasser, P.E., 2000: 10), "The (Kenya mission) report acknowledges that the informal sector idea originated not with the high-level foreign "development experts" brought in for the mission but from the work and the staff of the Institute or Development Studies of the University of Nairobi, a fact which has been generally forgotten since then. In other words, it was not the ILO that invented the informal sector concept. It came out of the thinkers and analysts of the Third World". Also on primacy in implementation of definition "informal economy" pretended paper (Hart, K., 1973), where the term informal economy was used to describe the activities undertaken by those who have been unsuccessful at earning an adequate income in the formal system. According to the Scopus database, the oldest publication, which focused on the shadow economy and published in 1974, is paper (Werlin, H.H., 1974). In this article, the authors examine the extent to which the ILO's proposals for handling problems arising in the "informal sector," within which hawkers and squatters are considered the most troublesome, are likely to be accepted by the Kenya government and the Nairobi City Council. This paper discussed the urban problem of employment policies and the informal sector of the economy. The most recent paper, according to Scopus, is (Rigon et al., 2020). In this article, the discussion on informality encompasses both the distinction drawn between informal and formal settlements and between informal and formal economic activities.

The oldest paper in this sphere, according to WoS database, is paper (Joshi et al., 1975), in which the authors examined the employment problems of the city of Abidjan in the Ivory Coast, which were created by three sets of imbalances: between the qualifications and aspirations of the indigenous labour force, and between these and the occupational structure of the demand for human resources in the formal sector of the urban economy, as well as the possibilities for human resources absorption in the informal sector and infrastructure expansion, before dealing briefly with the social problems of population pressure. The newest article in the "urban informal economy" sphere is paper (Young, G., 2020). In this study author draws on the extensive literature on informal economic activity more generally, with a focus on cities, to outline three contrasting perspectives on its significance for peacebuilding. He also claims that any effort to incorporate informal urban economies into peacebuilding processes must prioritize democratic inclusion, grassroots organisation, and formal employment creation if they are to have a meaningful impact on the urban poor's lives. A separate area of research is the shadow financial sector. The first work, according to the Scopus database, was published in 1991 (Fernando, N., 1991) and examines sources of informal savings and credit and the significant characteristics of the informal finance market. It is followed by a discussion of the significant arrangements of informal savings and credit in the economy. The newest paper (Canh, N.P., 2020) examines the influence of financial 
development in two main sub-sectors on the shadow economy's size based on the balanced panel data set of 114 economies for 2002-2015. Authors concluded that financial institutions' efficiency had a more significant effect on the shadow economy. Besides, the non-linear nexuses between economic development and shadow economy were U-shaped for some financial indicators; financial depth and financial access positively impacted the shadow economy in the short run, while financial institutions appeared to reduce it. According to WoS, the first paper in this area was published 1980 (Miracle, M., 1980) and presented a preliminary report on a more extensive study of mobilization of resources in the informal sector of African economies, focuses mainly on the savings accumulated through clubs or associations but also surveys the evidence on mobile (often ambulatory) bankers operating in African marketplaces. The last paper in this area (Valencia, G.A.D., et al., 2020) deals with analyzing the incidence of informal financing on the economic benefits of informal traders located in Cucuta's Colombian cities, Villavicencio and lbague, during the year 2017. Many publications deal with the government, policy and different institutions in decreasing the shadow economy level, etc. According to the Scopus database, the first work was published in 1982 (Petersen, H., 1982). It estimated that negative correlations between some kinds of public expenditures (or taxes) and the growth rate of real GNP should not be taken in proof of the growth-retarding effects which might ensue from increasing state activities and concluded that state activities had induced shifts of resources from the formal into the informal economy. The newest one is paper (Beqiraj et al., 2020) focused on counterfeiting and the economic effects of financial crime on Italy's trade during the economic crisis. It made the conclusion that the negative effects (the production (and exchange) of fake goods depresses the legal market that relies on intellectual property rights) outweigh the positive impact (supporting shadow-economic activities for the benefit of illegal workers, criminal organisations, and political clientele). According to WoS, the oldest article is paper (Feldbrugge, F. J. M., 1984), which gave the general character of the USSR's shadow economy, its specific sector, reasons, etc. The newest one - paper (Jahan et al., 2020), which uses data from 5,506 Brazilian municipalities to estimate institutions' effect on informal sector size.

The next area of publications is the correlation between the shadow economy and ecological problems or environmental pollution. According to the Scopus and WoS databases, the first work (Porter, R. A., 1983) was published in 1983. It arouses the problem of the informal sector and pollution of rural territory. The latest paper (Turcott Cervantes et al., 2020), in its strong correlation was detected between the development and implementation of legislation and policies on waste management and correct operation and a widespread presence of the informal sector in the service. According to WoS the most recent article (Goel, R.K. et al., 2020) presented results based on a panel of more than 130 nations and allowing for reverse causality, show both ownand border pollution reduce the underground sector consistent with the substitution effect. Another sphere of research is connections between the shadow economy and crime. The oldest article in this area, which references by Scopus, is paper (Scraton et al., 1984). The authors analyzed fifty-seven notes public sanctioning of corporate management's economic crimes and sanctioning for crimes typical of lower-class persons, understanding that persons from different socioeconomic classes have varying opportunities to engage in these offenses, work positions and class status, mostly taking to account the shadow economy. In a recent paper - article (Serrano-López, M., 2020), where the author describes the use of violence and corruption as profits maximizing factors for traffickers in the coca market. According to WoS, the oldest paper (Taylor, I., 1979). This article published a book review on the famous book (Henru, S., 1978) of Henru Stuart, that is a full-length contribution to what is a growth-point in the contemporary extension of the new deviancy theory into the investigation of empirical fields of investigation theft, fraud and other forms of property offence as species of regular social interaction in conditions of the hidden economy. The latest paper (Gupta, M.R., 2020) deals with the effects of economic globalization programs on criminal activities and the degree of skilled-unskilled wage inequality. Besides, many papers deal with education, skills and the hidden economy. According to WoS, the oldest article is a paper (King, K.J., 1975). It studied the acquisition of a wide variety of skills by low-income Kenya Africans, outside the scope of government and voluntary agency programs, that have important implications for the success of the government's official formal sector apprenticeship schemes, but indicates considerable difficulties for any attempt to identify this informal world as an independent sector of Kenya's broader economy. The most recent paper (Magidi, M., 2020) discovered that in Zimbabwe, the informal economy is also playing an equally important part in providing skills, especially to the disadvantaged groups of society, identify lack of recognition as one of the challenges that informal training programs encounter. The oldest paper in this sphere, according to the Scopus database (Watts, A. G., 1981), outlined the growing importance of three informal economies (the "black" economy, the "communal" economy, and the "household" economy) in education tends and the implications for careers education. The newest paper, which published the point of view of Alvaro Huerta, $\mathrm{PhD}$, holds a joint faculty appointment in Urban \& Regional Planning and Ethnic \& Women's Studies at California State Polytechnic University, Pomona, scholar and practitioner of the informal economy. (Huerta, A., 2020) about the connection between education and acquisition of skills in 
formal and informal economies. The findings proved that despite colossal range investigations of the shadow economy from different points of view, this problem was not analyzed yet considering various aspects of macroeconomic stability. In this case, the aim of the paper was to investigate the tendency in the scientific literature on the hidden economy to identify future research directions.

\section{Methodology}

The main hypothesis of investigation is to seek the increasing tendency on analyzing the shadow economy issues by the scientists. Thus, according to the paper (Vasylieva et al., 2020) the following scheme was used for investigation:

1. Identifying the quantity trends of publishing the articles, which is devoted to analyzing the shadow economy issues.

2. Allotting the main subject areas of publishing papers focused on the shadow economy.

3. Defining the most cited papers and Journals which contained the papers on the shadow economy.

4. Clustering the articles on the main areas for research to identify further directions for analyses.

The following keywords were chosen for the analysis: shadow economy, shadow sector of economy, informal economy, informal sector of the economy, underground economy, underground sector of the economy, hidden economy and hidden sector of the economy This study found 5361 papers from Scopus and 3773 papers from Web of Science associated with mentioned keywords. The time for analysis included all possible time samples (1970-2020 according to WoS) to define first paper and different areas of research. VOSviewer tools allow allocating and visualising the network of keywords mentioned in articles and co-citation during the research of the shadow economy issues and define direction with strong relationships (according to Vosviewer site the closer keywords are located to each other, the stronger their relations). Scopus and WoS tools were used to investigate country affiliation, journal, citation, number of the papers, the subject area and citations.

\section{Results}

The findings of analysis present that the amount of paper which devoted to the shadow economy in the database Scopus has been on same level up to 2002-2003, but after this year stated rising, with an average growth rate of $10 \%$. A similar situation is observed with the numbers of paper which focused on the shadow economy, which published in the journals indexed by the WoS database (average growth rate $-13 \%$ ), thus this database shows a significant growth rate of publications in 2014-2015. It can be attributed by the active discussion of the Transition from the Informal to the Formal Economy Recommendation, which was adopted in 2015 by the International Labor Organization as a powerful tool to advance towards the attainment of Sustainable Development Goals, especially Goal 8, which aims to "promote sustained, inclusive and sustainable economic growth, full and productive employment and decent work for all". In 2015 some papers which analyze the shadow economy, according to WoS database, was increased by $95 \%$ compared with the 2014 year, according to Scopus database - by $29 \%$ (Figure 1).

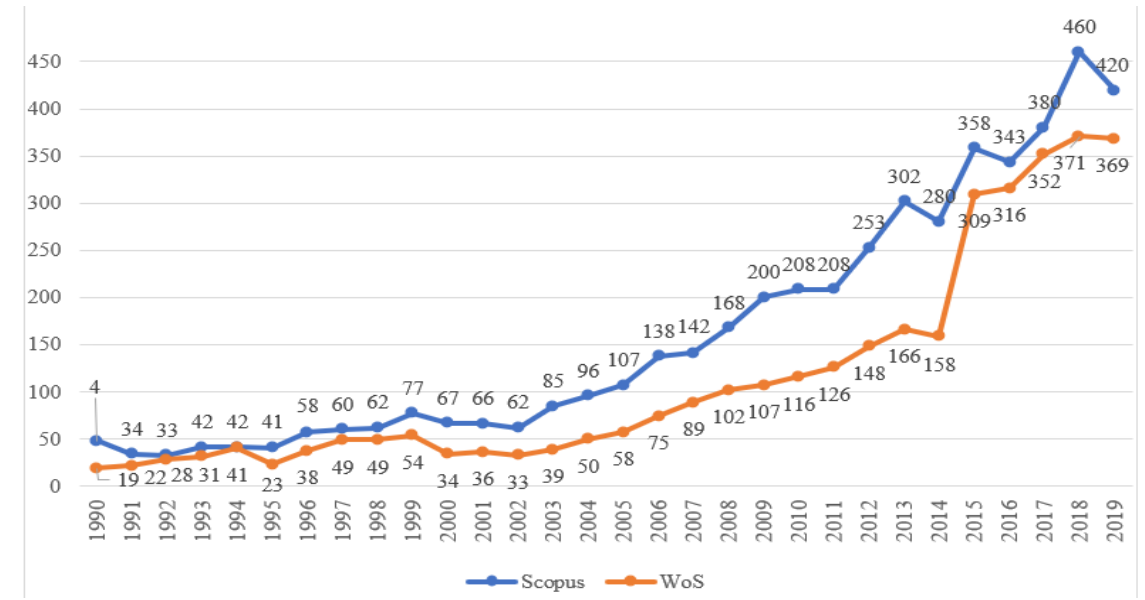

Figure 1. The number of documents in Scopus and WoS which contain the shadow economy issues Sources: Compiled by the authors using data from Scopus and WoS

The research proved that the shadow economy was analyzed according to data of Scopus in the framework of the subject area as follows: Social science - 35,96\%; Economics, Econometrics and Finance - 22,53\%; Business, Management and Accounting - 12,91\%; Environmental Science-5,44\%; Arts and Humanities - 6,05\%; and others (Earth and Planetary Sciences; Medicine; Engineering; Agricultural and Biological Sciences; Computer Science, etc.) - 17,11\% (Figure 2). According to data of WoS, in the framework of the subject area, the shadow economy was analyzed as follows: Business Economics - 34,85\%; Sociology - 5,75\%; Public 
Administration - 5,29\%; Government Law - 5,17\%; Development Studies - 4,37\%; Social Sciences Other Topics - 4,33\%; Environmental Sciences Ecology - 4,13\%; Area Studies - 4,07\% and others (Computer Science; Public Environmental Occupational Health; Urban Studies; Health Care Sciences Services; Engineering; Psychology; Geography; Demography, etc.) - 32,03\% (Figure 3).

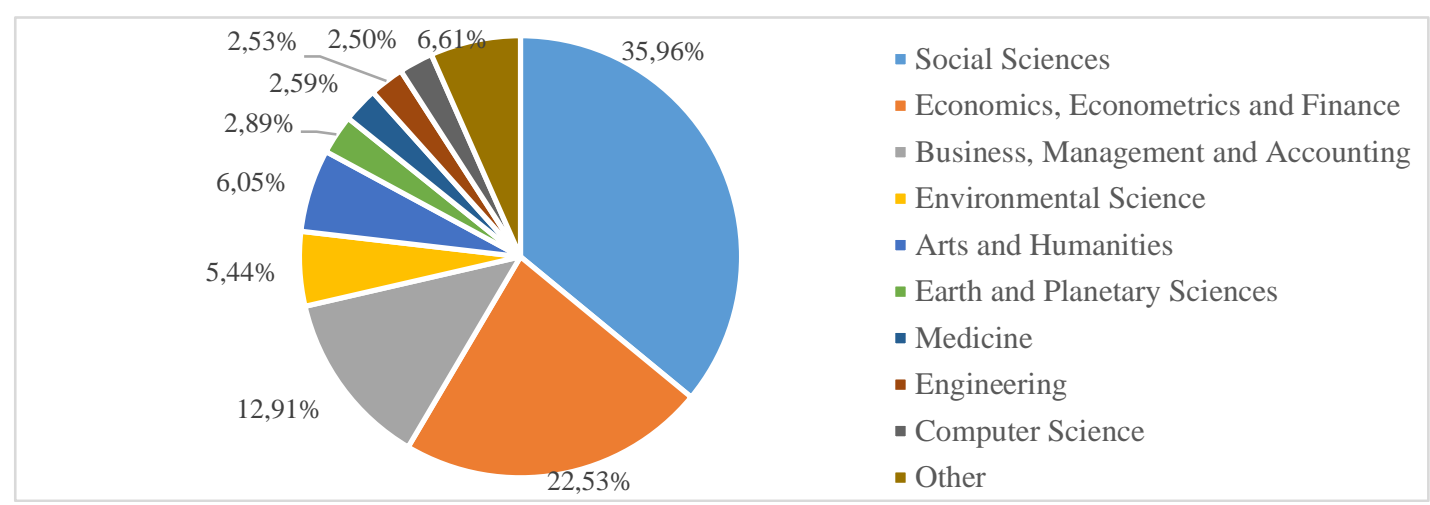

Figure 2. The subject area in Scopus for analysing the shadow economy issues

Sources: Compiled by the authors using data from Scopus

$\begin{aligned} & \text { - Business Economics } \\ & \text { - Sociology } \\ & \text { - Public Administration } \\ & \text { - Government Law } \\ & \text { - Development Studies } \\ & \text { - Social Sciences Other Topics } \\ & \text { - Environmental Sciences Ecology } \\ & \text { - Area studies } \\ & \text { - Geography } \\ & \text { - Urban Studies } \\ & \text { - Antropology } \\ & \text { - Other }\end{aligned}$

Figure 3. The subject area in WoS for analysing the shadow economy issues

Sources: Compiled by the authors using data from WoS

The country's analysis showed that mostly the scientist with the USA, United Kingdom, India, Germany, and South Africa affiliations investigated the shadow economy issues. According to the Scopus database, the top 20 countries' affiliation of the scientists studying the shadow economy issues is shown in Figure 4. Figure 4 also shows the number of publications from these countries in the WoS database.

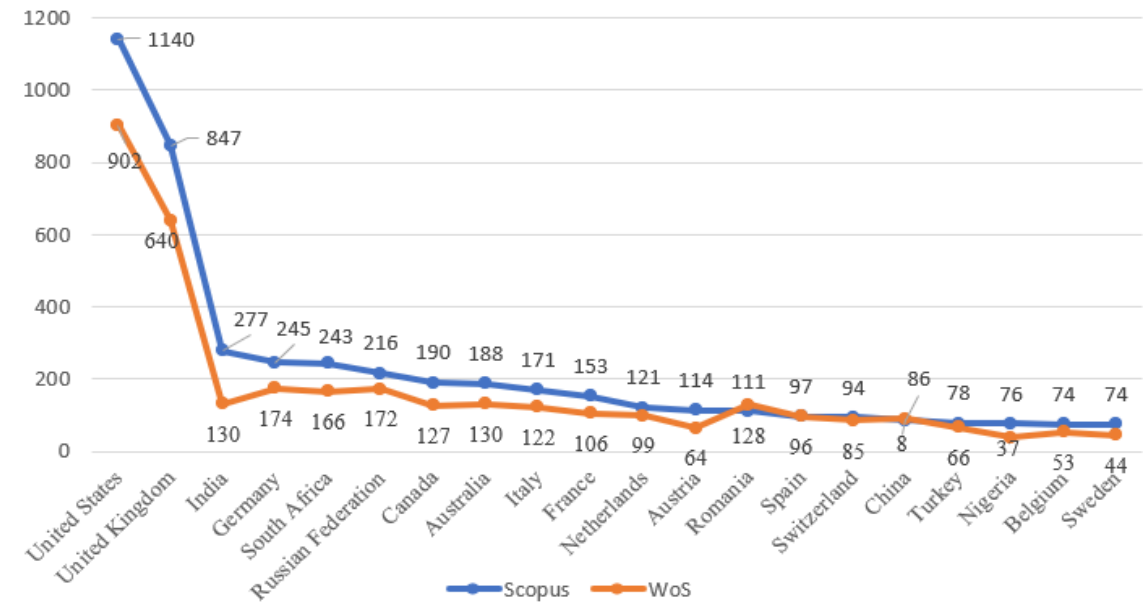

Figure 4. Top 20 country's affiliation of the scientists which investigated the shadow economy issues Sources: Compiled by the authors using data from WoS and Scopus

Besides, considering the findings from Scopus in 2019, such high ranked journals as Studies in Systems Decision and Control, Journal of Business Ethics, Journal of Contemporary Asia, Cities began to publish more papers on shadow economy issues. Only one from the five top Journals, indexed by Scopus, which published the papers on the shadow economy, is high ranking journal (SNIP>1) (Table 1). According to WoS, this 
indicator ( $\mathrm{SJR}>1$ ) is 2 from 5. According to Scopus database, 8 of 10 most cited papers were published by the high ranked Journals. The most cited papers were published by the Peruvian economist Hernando de Soto Polar in 1989 in book "The other path: the invisible revolution in the Third World" (De Soto, H., 1989) (Table 1). According to WoS database, the same situation of publishing -8 of 10 most cited papers were published by the high ranked Journals (Table 2). In 2007 Thorsten Beck, professor of banking and finance at Cass Business School in London, research fellow of the Centre for Economic Policy Research (CEPR) and the CESifo, the founding chair of the European Banking Center, scientist of the research department of the World Bank together with Asli Demirgüç-Kunt, Chief Economist of the Europe and Central Asia Region of the World Bank and Meghana Ayyagari published article (Ayyagari, M., 2007) which cited by Scopus ranking journal 338 times (Table 3) and by WoS ranking journal 290 times (Table 4). In this paper authors presented their finding that several dimensions of the business environment, such as lower costs of entry and better credit information sharing relate to a larger size of the SME sector, while higher exit costs - to a larger informal economy.

Table 1. The top 5 Journal, indexed by Scopus, which published the papers on the shadow economy

\begin{tabular}{|c|c|c|c|c|c|c|}
\hline Title of the Journal & $\begin{array}{l}\text { Covered by } \\
\text { Scopus }\end{array}$ & Subject area & $\begin{array}{l}\text { Cite } \\
\text { Score } \\
2019\end{array}$ & $\begin{array}{l}\text { SJR } \\
2019\end{array}$ & $\begin{array}{l}\text { SNIP } \\
2019\end{array}$ & $\begin{array}{c}\text { Number } \\
\text { of the } \\
\text { papers }\end{array}$ \\
\hline World Development & 1973 to 2021 & $\begin{array}{l}\text { Social Sciences: Development, Sociology } \\
\text { and Political Science, Geography, } \\
\text { Planning and Development; Economics, } \\
\text { Econometrics and Finance: Economics } \\
\text { and Econometrics }\end{array}$ & 7.1 & 2.223 & 2.880 & 56 \\
\hline $\begin{array}{l}\text { Indian Journal of Labour } \\
\text { Economics }\end{array}$ & $\begin{array}{c}1996, \\
1998 \text { to } 2013, \\
2015 \text { to Present }\end{array}$ & $\begin{array}{l}\text { Economics, Econometrics and Finance: } \\
\text { Economics and Econometrics }\end{array}$ & 0.2 & 0.125 & 0.956 & 34 \\
\hline $\begin{array}{l}\text { Journal of Developmental } \\
\text { Entrepreneurship }\end{array}$ & 2008 to Present & $\begin{array}{l}\text { Business, Management and Accounting: } \\
\text { Business and International Management, } \\
\text { Strategy and Management; Economics, } \\
\text { Econometrics and Finance: Economics } \\
\text { and Econometrics }\end{array}$ & 1.4 & 0.273 & 0.535 & 35 \\
\hline $\begin{array}{l}\text { International Journal of } \\
\text { Sociology and Social } \\
\text { Policy }\end{array}$ & 1981 to Present & $\begin{array}{c}\text { Economics, Econometrics and Finance: } \\
\text { General Economics, Econometrics and } \\
\text { Finance; Social Sciences: Sociology and } \\
\text { Political Science }\end{array}$ & 1.5 & 0.252 & 0.662 & 54 \\
\hline Applied Economics & 1969 to Present & $\begin{array}{l}\text { Economics, Econometrics and Finance: } \\
\text { Economics and Econometrics }\end{array}$ & 1.9 & 0.468 & 0.939 & 29 \\
\hline
\end{tabular}

Sources: Compiled by the authors using data from Scopus

Table 2. The top 5 Journal, indexed by WoS, which published the papers on the shadow economy

\begin{tabular}{|c|c|c|c|c|c|}
\hline Title of the Journal & H Index & Quartiles & $\begin{array}{l}\text { SJR } \\
2019\end{array}$ & $\begin{array}{l}\text { Quartile in } \\
\text { Category }\end{array}$ & $\begin{array}{c}\text { Numbers } \\
\text { of the } \\
\text { papers }\end{array}$ \\
\hline World Development & 164 & Economics and Econometrics & 2,22 & Q1 & 35 \\
\hline Applied Economics & 78 & Economics and Econometrics & 0,47 & Q2 & 30 \\
\hline \multirow{3}{*}{$\begin{array}{l}\text { International Journal of } \\
\text { Urban and Regional Research }\end{array}$} & \multirow{3}{*}{105} & Development & \multirow{3}{*}{2,65} & \multirow{3}{*}{ Q1 } & \multirow{3}{*}{29} \\
\hline & & Sociology and Political Science & & & \\
\hline & & Urban Studies & & & \\
\hline \multirow{3}{*}{$\begin{array}{l}\text { Journal of Developmental } \\
\text { Entrepreneurship }\end{array}$} & \multirow{3}{*}{23} & Business and International Management & \multirow{3}{*}{0,27} & \multirow{3}{*}{ Q3 } & \multirow{3}{*}{27} \\
\hline & & Strategy and Management & & & \\
\hline & & Economics and Econometrics & & & \\
\hline \multirow{2}{*}{$\begin{array}{l}\text { International Journal of } \\
\text { Sociology and Social Policy }\end{array}$} & \multirow{2}{*}{68} & $\begin{array}{c}\text { Economics, Econometrics and Finance } \\
\text { (miscellaneous) }\end{array}$ & \multirow{2}{*}{0,25} & \multirow{2}{*}{ Q2 } & \multirow{2}{*}{25} \\
\hline & & Sociology and Political Science & & & \\
\hline
\end{tabular}

Sources: Compiled by the authors using data from Scimagojr and WoS

According to the WoS database, the most cited paper in 1990-2019 was an article (Schneider et al., 2000) of Friedrich Schneider, Professor of Economics at Johannes Kepler University of Linz, Austria, Finance Institute, Linz, Austria and Research Professor at the German Institute for Economic Research, Berlin, Germany, who is the famous specialist in the shadow economy, author of many publications in shadow economy among Woking paper of IMF and World bank. This article was cited by the WoS ranking journal 907 times (Table 3). In this paper, authors used various methods to estimate the size of the shadow economy in 76 developing, transition, and OECD countries; examined different determinants of its growth (taxation, social security contributions, state regulations, corruption, etc.) and calculated the effect of growing shadow economy on official GDP growth. Among ten the most cited papers, there is an article (Loayza, N.V., 1996) of Norman 
Loayza, a Lead Economist in the Development Research Group at the World Bank. He headed the Asia hub of the Research Group, based in Malaysia and was director of the World Development Report 2014, Risk and Opportunity: Managing Risk for Development. The paper (Loayza, N.V., 1996) was cited by WoS ranking journal 252 times and presented the view that among of the most impotent reason for the informal economy rising can be mentioned 1) excessive taxes; 2) excessive regulations (which are imposed by governments); 3)impossibility of government to influence strict observance of the implemented norms and laws. The author based his research on the endogenous growth model whose production technology depends on public services. The paper uses data from Latin American countries in the early 1990s. Conclusions of the article are the following: 1) size of the shadow sector of the economy is found to depend positively on proxies for tax burden and labor-market restrictions, and negatively on a proxy for the quality of government institutions; 2) changes in policy parameters and the government institutions quality that promote an increase in the relative size of the informal economy, will generate the economic growth rate reduction; 3) an increase in the informal sector size negatively affects growth, first, by reducing the availability of public services for everyone in the economy, and, second, increasing the number of activities that use some of the existing public services less efficiently or not at all.

Table 3. The most cited papers on the i shadow economy 1950-2020 according to Scopus database

\begin{tabular}{|c|c|c|c|}
\hline Authors and Title & Year & Source title & Cited \\
\hline $\begin{array}{l}\text { De Soto, H. The other path: the invisible revolution in the Third World } \\
\text { (Article) }\end{array}$ & 1989 & $\begin{array}{l}\text { The other path: the invisible } \\
\text { revolution in the Third World }\end{array}$ & 1212 \\
\hline $\begin{array}{l}\text { Schneider, F., Enste, D.H. Shadow Economies: Size, Causes, and } \\
\text { Consequences }\end{array}$ & 2000 & Journal of Economic Literature & 1117 \\
\hline $\begin{array}{l}\text { Seto, Karen C.; Fragkias, Michail; Gueneralp, Burak, et al. A Meta-Analysis } \\
\text { of Global Urban Land Expansion }\end{array}$ & 2011 & PLOS ONE & 876 \\
\hline $\begin{array}{l}\text { Smith, N. Toward a theory of gentrification: A back to the city movement by } \\
\text { capital, not people }\end{array}$ & 1979 & $\begin{array}{l}\text { Journal of the American Planning } \\
\text { Association }\end{array}$ & 789 \\
\hline $\begin{array}{l}\text { Guttentag, D. Airbnb: disruptive innovation and the rise of an informal } \\
\text { tourism accommodation sector }\end{array}$ & 2015 & Current Issues in Tourism & 564 \\
\hline $\begin{array}{l}\text { Webb, Justin W.; Tihanyi, Laszlo; Ireland, R. Duane, et al. You say illegal, } \\
\text { I say legitimate: entrepreneurship in the informal economy }\end{array}$ & 2009 & Academy of Management Review & 481 \\
\hline Breman, J. Footloose labour: working in India's informal economy (Book) & 1996 & $\begin{array}{l}\text { Footloose labour: working in India's } \\
\text { informal economy }\end{array}$ & 427 \\
\hline $\begin{array}{l}\text { Kloosterman, R., Van der Leun, J., Rath, J., Mixed embeddedness: } \\
\text { (In)formal economic activities and immigrant businesses in the Netherlands }\end{array}$ & 1999 & $\begin{array}{l}\text { International Journal of Urban and } \\
\text { Regional Research }\end{array}$ & 411 \\
\hline $\begin{array}{l}\text { Schneider, F. Shadow economies around the world: What do we really } \\
\text { know? }\end{array}$ & 2005 & $\begin{array}{l}\text { European Journal of Political } \\
\text { Economy }\end{array}$ & 398 \\
\hline $\begin{array}{l}\text { Ayyagari, M., Beck, T., Demirguc-Kunt, A. Small and medium enterprises } \\
\text { across the globe }\end{array}$ & 2007 & Small Business Economics & 338 \\
\hline
\end{tabular}

Sources: Compiled by the authors using data from Scopus

Table 4. The most cited papers on the shadow economy 1970-2020 according to WoS database

\begin{tabular}{|l|c|c|c|}
\hline \multicolumn{1}{|c|}{ Authors and Title } & Year & Source title & Cited \\
\hline $\begin{array}{l}\text { Schneider, F., Enste, D.H. Shadow economies: Size, causes, and } \\
\text { consequences }\end{array}$ & 2000 & Journal of Economic Literature & 907 \\
\hline $\begin{array}{l}\text { Seto, Karen C.; Fragkias, Michail; Gueneralp, Burak, et al. A Meta-Analysis } \\
\text { of Global Urban Land Expansion }\end{array}$ & 2011 & PLoS ONE & 833 \\
\hline $\begin{array}{l}\text { Webb, Justin W.; Tihanyi, Laszlo; Ireland, R. Duane, et al. You say illegal, } \\
\text { I say legitimate: entrepreneurship in the informal economy }\end{array}$ & 2009 & Academy of Management Review & 401 \\
\hline $\begin{array}{l}\text { Kloosterman, R., Van der Leun, J., Rath, J., Mixed embeddedness: } \\
\text { In)formal economic activities and immigrant businesses in the Netherlands }\end{array}$ & 1999 & $\begin{array}{c}\text { International Journal of Urban and } \\
\text { Regional Research }\end{array}$ & 384 \\
\hline $\begin{array}{l}\text { Alm, J., Torgler, B. Culture differences and tax morale in the united states } \\
\text { and in Europe. }\end{array}$ & 2006 & Journal of Economic Psychology & 303 \\
\hline $\begin{array}{l}\text { Ayyagari, M., Beck, T., Demirguc-Kunt, A. Small and medium enterprises } \\
\text { across the globe }\end{array}$ & 2007 & Small Business Economics & 290 \\
\hline $\begin{array}{l}\text { Gërxhani, K. The informal sector in developed and less developed countries: } \\
\text { A literature survey. }\end{array}$ & 2004 & Public Choice & 263 \\
\hline $\begin{array}{l}\text { Schneider, F., Buehn, A., Montenegro, C. E. New Estimates for the Shadow } \\
\text { Economies all over the World }\end{array}$ & 2010 & International Economic Journal & 258 \\
\hline $\begin{array}{l}\text { Loayza, N.V. The economics of the informal sector: A simple model and } \\
\text { some empirical evidence from Latin America }\end{array}$ & 1996 & $\begin{array}{c}\text { Carnegie-Rochester Conference on } \\
\text { Public Policy - Essays in Honor of } \\
\text { Carl }\end{array}$ & 252 \\
\hline $\begin{array}{l}\text { Jayanthakumaran, K., Verma, R., Liu, Y. CO2 emissions, energy } \\
\text { consumption, trade and income: A comparative analysis of China and India }\end{array}$ & 2012 & Energy Policy \\
\hline
\end{tabular}

Sources: Compiled by the authors using data from WoS.

The findings from VOSviewer identified six clusters of the papers which investigated the shadow economy from the different points of views (Figure 5). 


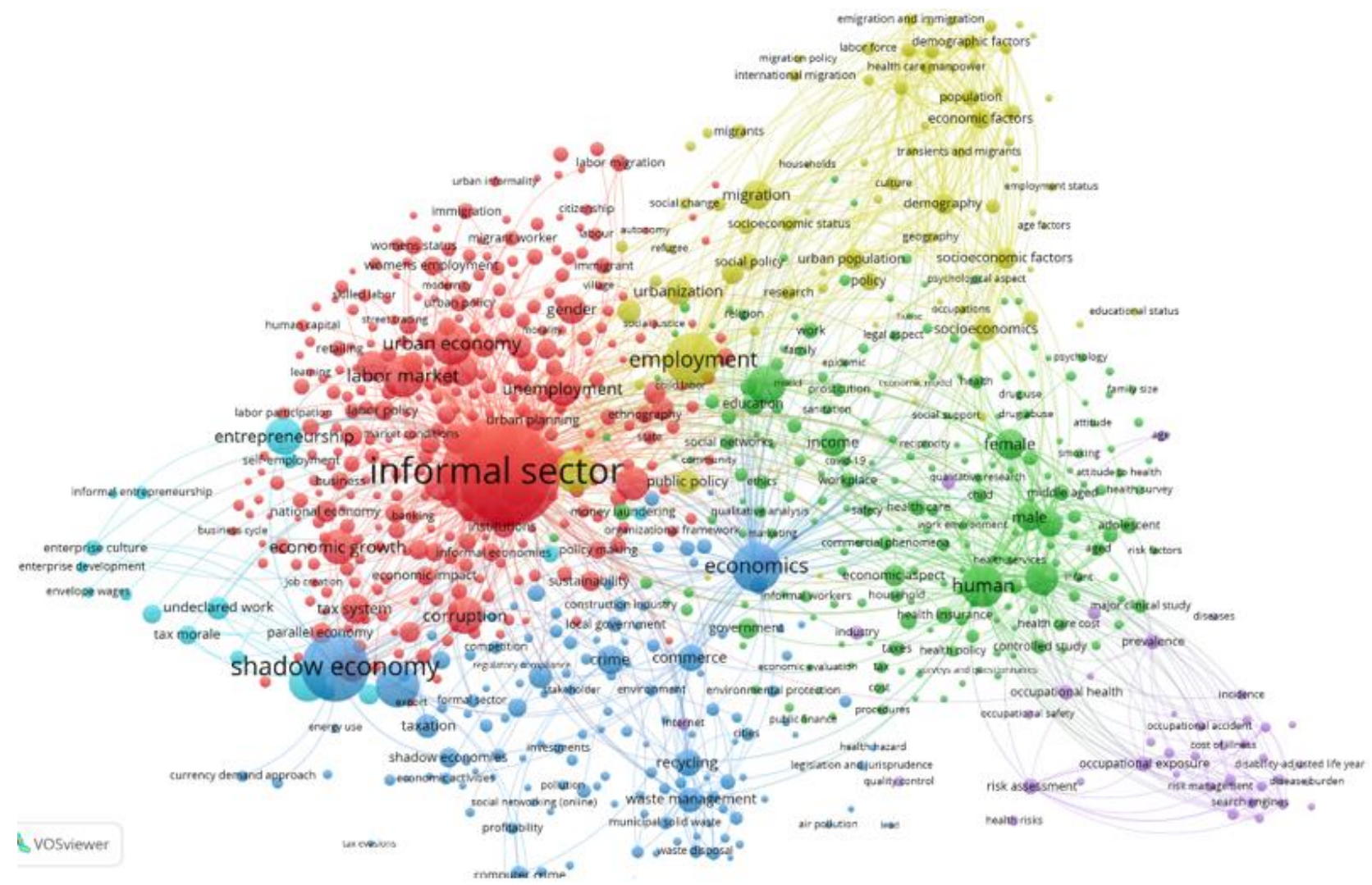

Figure 5. The network visualisation of the co-citation of the papers on the shadow economy issues Source: Compiled by the authors using the Scopus and WoS database and VOSviewer tool

The first biggest cluster (red cluster -310 items) merged the paper which contained the keywords as follows: informal sector, informal economy, unemployment, gender, urban economy, labour market, corruption etc. (Figure 6).

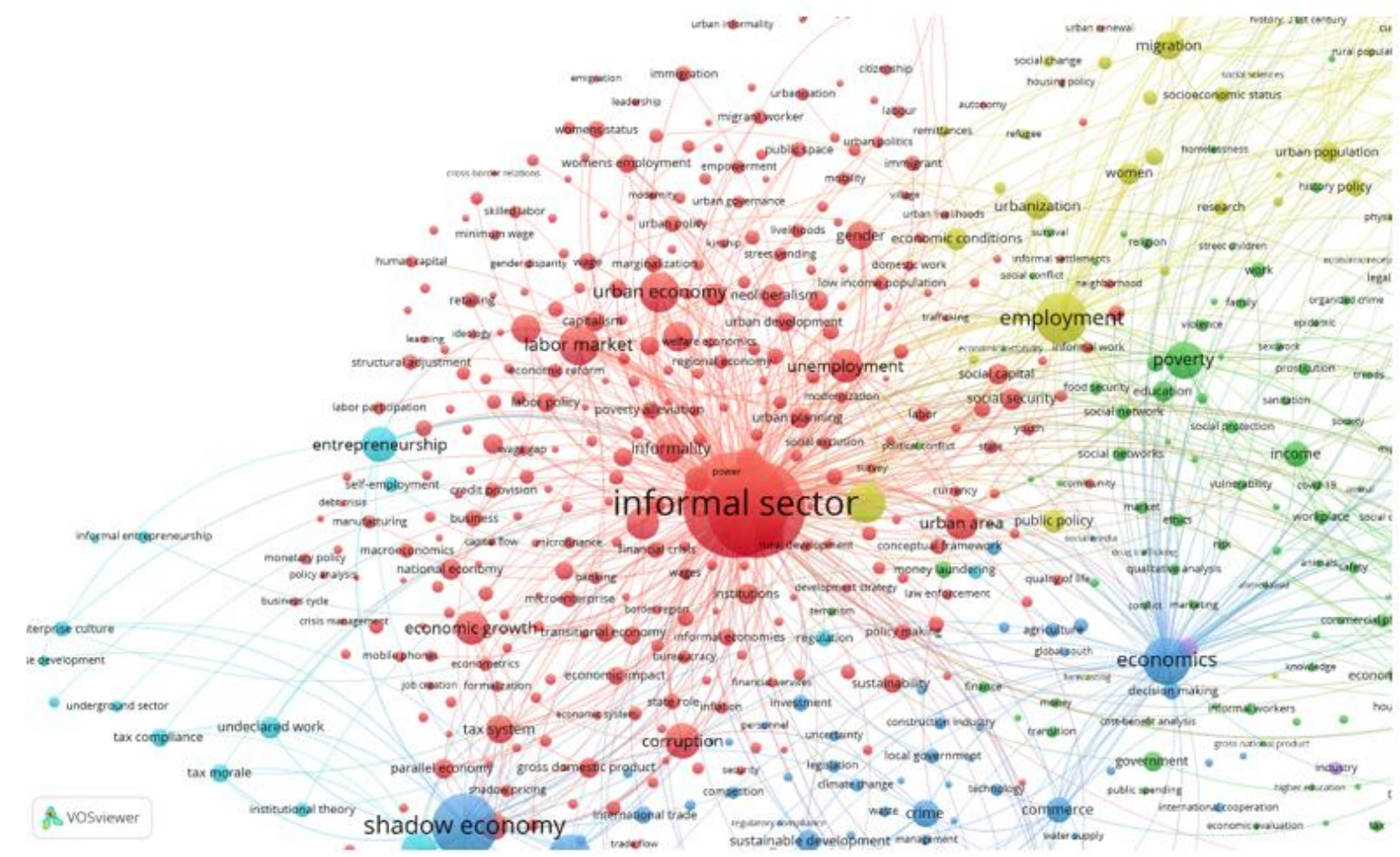

Figure 6. The network visualisation of the co-citation of the papers on the shadow economy with close areas (red cluster) Sources: Compiled by the authors using the Scopus and WoS database and VOSviewer tool

The second biggest cluster (green cluster - 203 items) contained such issues as follows: human, poverty, male, female, education, young adult, adolescent, social protection, social network etc. The third biggest cluster (blue 
cluster - 138 items) focused on the next keywords: shadow economy, underground economy, waste, waste management, recycling, sustainable development, crime, economics, economic activity etc. The fourth biggest cluster (yellow one -81 items) merged the paper, which contained the keywords as follows: demography, employment, migration, socioeconomics, socioeconomic factor, economic development, urbanisation, policy etc. (Figure 7)

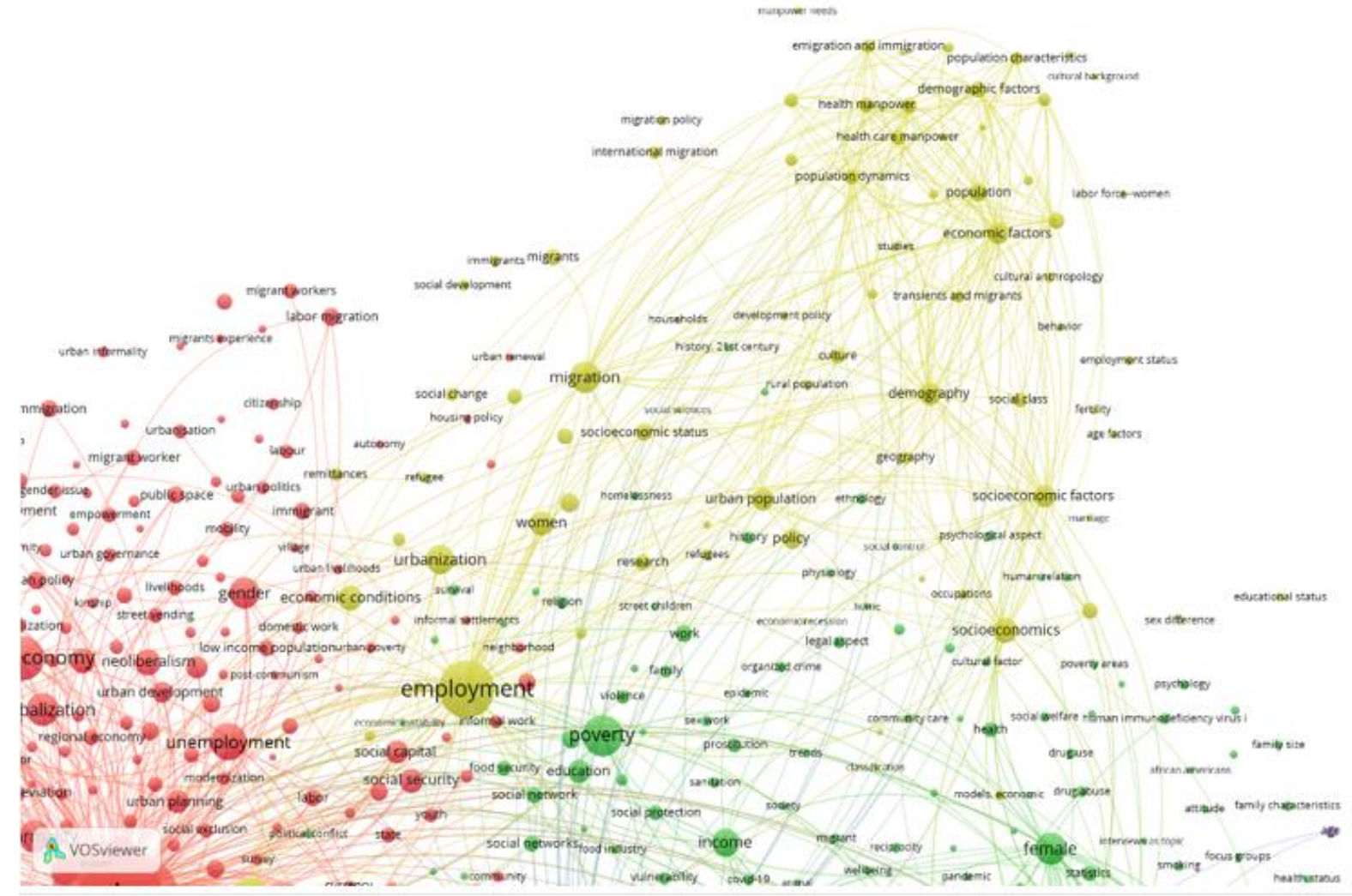

Figure 7. The network visualisation of the co-citation of the keywords on yellow cluster

Sources: Compiled by the authors using the Scopus and WoS database and VOSviewer tool

Next cluster (purple - 40 items) located close to second one (green) contained such issues as follows: working condition, risk assessment, occupation health, prevalence, occupation exposure, mortality, cost of illness etc. They are connected threw the word "occupation health / occupation exposure - human/ male/ workplace", also purple cluster connected to red and yellow clusters threw keyword "working condition - informal sector/labour market - employment" etc. The closer location of the abovementioned cluster to each other proved the stronger their relations. Such tendency allows making a conclusion, that health problems affected by employment on informal sector of labour market are very close and popular in difference issues. The findings proved that this connection become important part of issues among ILO, World bank and WHO. (Figure 8). 


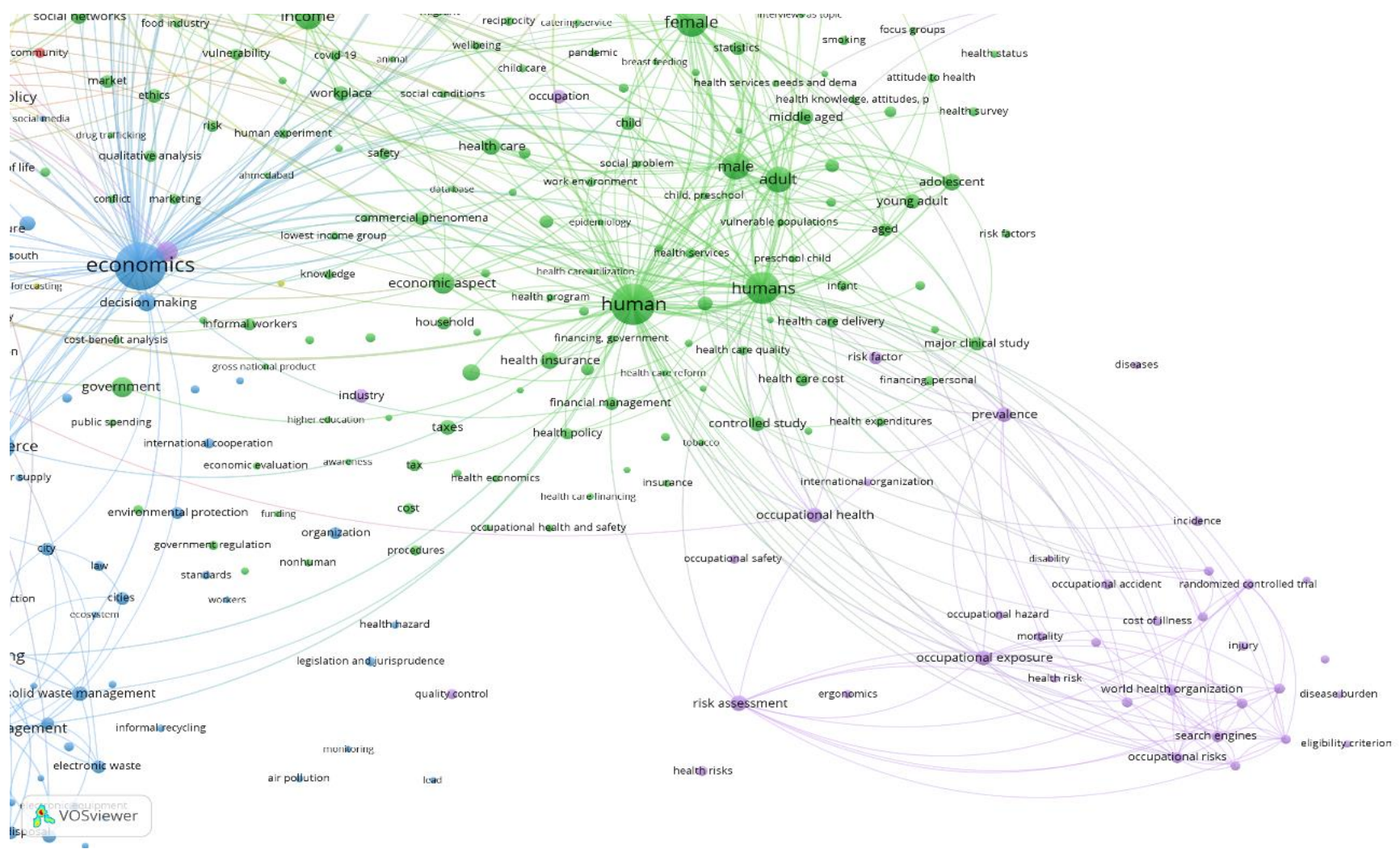

Figure 8. The network visualisation of the co-citation of the papers on the shadow economy with close areas (purple cluster) Sources: Compiled by the authors using the Scopus and WoS database and VOSviewer tool

Considering the results, 6 clusters. The biggest was red, green, blue and yellow. In this case, the red cluster contained keywords as follows: relating to informal economy and labour market. Thus, the findings proved the research hypothesis that the topic of informal employment in the papers which analysed the shadow economy issues are very popular. At the same time, the most related areas with the hidden economy were labour market, urban economy, poverty, entrepreneurship and crime.

\section{Conclusion}

The analysis results proved that the informal economy is a popular direction for investigation, formed in the separate scientific school. The number of papers increased from 2014. It was caused by the active discussion of the Transition from the Informal to the Formal Economic Recommendation, adopted by the International Labor Organization in 2015. The findings from VOSviewer allow allocating six clusters. Five of six clusters have a close relationship. The first biggest cluster relating to offenses in the informal economy and labour market. The second biggest cluster merged such keywords as human, poverty, male, female, education, young adult, adolescent, social protection, social network, etc. The third biggest cluster focused on criminal and ecological aspects of the shadow economy. The fourth biggest cluster (the yellow one) merged the paper related to demography, migration and socioeconomic factor. A small purple cluster is located close to the second one (green). Such a tendency allows concluding that health problems affected by employment in the informal sector of labour market are very close and famous in different issues.

Author Contribution. Conceptualization, Zolkover Andrii, Venelin Terziev; data curation, Zolkover Andrii; formal analysis, Zolkover Andrii; funding acquisition, Zolkover Andrii; investigation, Zolkover Andrii; methodology, Zolkover Andrii; project administration, Zolkover Andrii; resources, Zolkover Andrii; Software: Zolkover Andrii; supervision, Zolkover Andrii, Venelin Terziev; validation, Venelin Terziev; visualisation, Venelin Terziev; writing - original draft, Zolkover Andrii, Venelin Terziev; writing- review and editing, Zolkover Andrii, Venelin Terziev.

Funding. This research was funded solely by the authors.

\section{References}

1. Alm, J., \& Torgler, B. (2006). Culture differences and tax morale in the united states and in Europe. Journal of Economic Psychology, 27(2), 224-246. doi:10.1016/j.joep.2005.09.002. 
2. Ayyagari, M., Beck, T., \& Demirguc-Kunt, A. (2007). Small and medium enterprises across the globe. Small Business Economics, 29(4), 415-434. doi:10.1007/s11187-006-9002-5.

3. Bangasser, Paul E. (2000). The ILO and the Informal Sector: An Institutional History. Geneva: ILO, 10. Available at: ed_emp/documents/publication/wcms_142295.pdf.

https://www.ilo.org/wcmsp5/groups/public/---

4. Breman, J. (1996). Footloose labour: Working in India's informal economy. 278p. Available at: Www.scopus.com.

5. Canh, N. P., \& Thanh, S. D. (2020). Financial development and the shadow economy: A multi-dimensional analysis. Economic Analysis and Policy, 67, 37-54. doi:10.1016/j.eap.2020.05.002.

6. De Soto, H. (1989). The other path: The invisible revolution in the third world. Available at: www.scopus.com.

7. Employment, incomes and equity: a strategy for increasing productive employment in Kenya (ILO, Geneva, 1972). The following quote is from pages $5 \& 6$ of the Introduction. Available at: https://www.ilo.org/public/libdoc/ilo/1972/72B09_608_engl.pdf.

8. Feldbrugge, F. J. M. (1984). Government and shadow economy in the Soviet Union. Soviet Studies, 36(4), 528-543. doi:10.1080/09668138408411553.

9. Fernando, N. (1991). Informal finance in a semi-subsistence economy: A case of Papua New Guinea. NRI Discussion Paper - National Research Institute, Papua New Guinea, 62. Available at: www.scopus.com.

10.Gërxhani, K. (2004). The informal sector in developed and less developed countries: A literature survey. Public Choice, 120(3-4), 267-300. doi:10.1023/B:PUCH.0000044287.88147.5e.

11.Gupta, M. R. (2020). Globalisation, crime and wage inequality: A theoretical analysis. Indian Growth and Development Review, (ahead of print). doi:10.1108/IGDR-12-2019-0132.

12.Guttentag, D. (2015). Airbnb: Disruptive innovation and the rise of an informal tourism accommodation sector. Current Issues in Tourism, 18(12), 1192-1217. doi:10.1080/13683500.2013.827159.

13.Goel, R. K., \& Saunoris, J. W. (2020). Spatial spillovers of pollution onto the underground sector. Energy Policy, 144. doi:10.1016/j.enpol.2020.111688.

14.Hart, K. (1973). Informal income opportunities and urban employment in Ghana. The Journal of Modern African Studies, 11(1), 61-89. DOI: https://doi.org/10.1017/S0022278X00008089.

15.Henru, S. (1978). The Hidden Economy: the context and control of borderline crime. London, Martin Robertson, 194 pp. (book). Available at: https://www.vosviewer.com/.

16.Huerta, A. (2020). Viewpoint: An education in the informal economy. Planning, 86(1), 13. Available at: www.scopus.com.

17.Jahan, I., Pavlik, J.B., Williams, R.B. (2020). Is the devil in the shadow? The effect of institutional quality on income. Review of Development Economics, 00, 1-21. https://doi.org/10.1111/rode.12691.

18.Jayanthakumaran K, Verma R., Liu Y. (2012). CO2 emissions, energy consumption, trade and income: a comparative analysis of China and India. Energy Policy, 42, 450-460. https://doi.org/10.1016/J.ENPOL.2011.12.010.

19.Joshi, H., Lubell, H., \& Mouly, J. (1975). Urban development and employment in Abidjan. International Labour Review, 111(4), 289-306. Available at: www.scopus.com.

20.King, K. J. (1975). Skill acquisition in the informal sector of an African economy: The Kenya case. The Journal of Development Studies, 11(2), 108-122. doi:10.1080/00220387508421528.

21.Kloosterman, R., Van Leun, J. D., \& Rath, J. (1999). Mixed embeddedness: (in)formal economic activities and immigrant businesses in the Netherlands. International Journal of Urban and Regional Research, 23(2), 252-266. doi:10.1111/1468-2427.00194.

22.Lewis, W. Arthur. (1955). The theory of economic growth. London: Allen and Unwin. Available at: https://www.amazon.com/Theory-Economic-Growth-Arthur-Lewis-ebook-dpB00CUFK45E/dp/B00CUFK45E/ref=mt other? encoding $=\mathrm{UTF} 8 \& \mathrm{me}=\& \mathrm{qid}=$

23.Loayza, N.V. (1996). The economics of the informal sector: a simple model and some empirical evidence from Latin America. Carnegie-Rochester Conference Series on Public Policy, 45(1), 129-162. https://doi.org/10.1016/S0167-2231(96)00021-8.

24.Magidi, M., \& Mahiya, I. T. (2020). Rethinking training: The role of the informal sector in skills acquisition and development in Zimbabwe. Development Southern Africa. doi:10.1080/0376835X.2020.1799759.

25.Miracle, M., Miracle, D., \& Cohen, L. (1980). Informal Savings Mobilization in Africa. Economic Development and Cultural Change, 28(4), 701-724. Retrieved September 18, 2020, from http://www.jstor.org/stable/1153518. 
26.Petersen, H. (1982). Size of the public sector, economic growth and the informal economy: development trends in the Federal Republic of Germany. Review of Income and Wealth, 28(2), 191-215. doi:10.1111/j.1475-4991.1982.tb00612.x.

27.Porter, R. A. (1983). Ecological strategies of prevention in rural community development. The Journal of Primary Prevention, 3(4), 235-243. doi:10.1007/BF01325406.

28.Rigon, A., Walker, J., \& Koroma, B. (2020). Beyond formal and informal: Understanding urban informalities from freetown. Cities, 105. doi:10.1016/j.cities.2020.102848.

29.Seto, K.C., Fragkias, M., Güneralp, B., \& Reilly, M.K. (2011). A meta-analysis of global urban land expansion. PLoS ONE, 6(8), e23777. doi:10.1371/journal.pone.0023777.

30.Smith, N. (1979). Toward a theory of gentrification: A back to the city movement by capital, not people. Journal of the American Planning Association, 45(4), 538-548. doi:10.1080/01944367908977002.

31.Schneider, F. (2005). Shadow economies around the world: What do we really know? European Journal of Political Economy, 21(3), 598-642. doi:10.1016/j.ejpoleco.2004.10.002.

32.Schneider, F., Buehn, A., \& Montenegro, C.E. (2010). New estimates for the shadow economies all over the world. International Economic Journal, 24(4), 443-461. doi:10.1080/10168737.2010.525974.

33.Schneider, F., \& Enste, D.H. (2000). Shadow economies: Size, causes, and consequences. Journal of Economic Literature, 38(1), 77-114. doi:10.1257/jel.38.1.77.

34.Scraton, P., \& South, N. (1984). The ideological construction of the hidden economy: Private justice and work-related crime. Contemporary Crises, 8(1), 1-18. doi:10.1007/BF00729541.

35.Serrano-López, M. (2020). Violence and corruption as maximization strategies in illegal markets: The case of coca. [Violencia y corrupción como estrategias de maximización en mercados ilegales: El caso de la coca]. Cuadernos De Economia (Colombia), 39(81), 949-974. doi:10.15446/cuad.econ.v39n81.56155.

36.Taylor, I. (1979). Book Review: The Hidden Economy: the context and control of borderline crime. Sociology, 13(2), 325-327. doi:10.1177/003803857901300217.

37.The 2030 development agenda. Targets for Goal \#8: Decent work and economic growth. Available at: https://www.ilo.org/global/topics/sdg-2030/goal-8/WCMS_403787/lang--en/index.htm.

38. Transition from the Informal to the Formal Economy Recommendation. Available at: https://www.ilo.org/public/english/standards/relm/ilc/ilc90/pdf/pr-25res.pdf.

39.Turcott Cervantes, D.E., Romero, E.O., del Consuelo Hernández Berriel, M., Martínez, A. L., del Consuelo Mañón Salas, M., \& Lobo, A. (2021). Assessment of some governance aspects in waste management systems: A case study in Mexican municipalities. Journal of Cleaner Production, 278. doi:10.1016/j.jclepro.2020.123320.

40.Valencia, G.A.D., Norato, O.M.G., Paez, A.A.V., Romero, R. (2020). Informal forms of financing of informal merchants in Colombia Cases: Cucuta, Ibague and Villavicencio. Cuadernos de Economia, 42(123), 259-274. DOI: 10.32826/cude.v43i123.126.

41.Vasylieva, T., Bilan, Y., Starchenko, L., Woźniak, A. (2020). Green intellectual capital for sustainable business model: bibliometric analysis. In Proceedings of the 34th International Business Information Management Association (IBIMA) conference. Available at: https://ibima.org/conference/35th-ibima-conference/.

42.Watts, A. G. (1981). Careers education and the informal economies. British Journal of Guidance \& Counselling, 9(1), 24-35. doi:10.1080/03069888108258198.

43.Webb, J.W., Tihanyi, L., Ireland, R.D., \& Sirmon, D.G. (2009). You say illegal, I say legitimate: Entrepreneurship in the informal economy. Academy of Management Review, 34(3), 492-510. doi:10.5465/AMR.2009.40632826.

44.Werlin, H.H. (1974). The informal sector: The implications of the ILO's study of Kenya. African Studies Review, 17(1), 205-212. doi:10.2307/523586.

45.Young, G. (2020). Urban informal economies in peacebuilding: Competing perspectives and implications for theory and praxis. Third World Quarterly. doi:10.1080/01436597.2020.1799192. 